\title{
Sex Equity in Mathematics and Science Education: Research-Policy Links
}

\author{
Janis E. Jacobs and Allan Wigfield ${ }^{2,3}$
}

Despite the accumulation of a large body of research concerning effective sex equity practices in math and science, the lack of change in educational procedures suggests the need to reexamine the role of research in policy and program planning. This paper reviews the current research on sex equity in mathematics and science education, focusing on research in the categories of educator-student interaction, instructional context, and macrolevel demographics. Existing applications of current research to mathematics and science education programs are examined at regional, state, district, and individual school levels. Recommendations for future directions in policy and research are made, emphasizing the gaps in knowledge on each side. The paper ends with specific suggestions for strengthening the links between research and policy in the area of sex equity.

KEY WORDS: sex differences; mathematics; sex equity; instruction.

\section{INTRODUCTION}

In the last 10 years, educational practices have been the target of much criticism in this country. Beginning with the report of the National Commission on Excellence in Education (1983), this dissatisfaction has been expressed publicly by senators, policy analysts, and educators themselves. One of the few things not under fire has been the question of sex equity in the schools. Clark and Astuto (1986) suggest that the Commission's report, titled $A \mathrm{Na}$ tion at Risk, "switched the attention of educational reformers and policymakers from equity to excellence. The argument of the report is essentially

\footnotetext{
'Department of Psychology, University of Nebraska, Lincoln, Nebraska 68588.

${ }^{2}$ Institute for Social Research, University of Michigan, Ann Arbor, Michigan 48109.

${ }^{3}$ Present address: Department of Human Development, College of Education, University of Maryland, College Park, Maryland 20742.
} 
that excellence begets true equity" (p. 6). Does this mean that the goal of equitable education for boys and girls has been reached? Although great strides have been made, equity in the classroom remains elusive. This is particularly true for mathematics and science education, where recent research still points to gender differences in achievement.

Females are more likely than males to receive high grades in mathematics throughout their precollege years; however, they score lower on the mathematics section of the Scholastic Aptitude Test before entering college (National Science Foundation, 1984). According to the National Science Foundation (NSF) (1985), women still earn only $14 \%$ or fewer of the doctorates in mathematics, physical science, and engineering. Although women make up about $45 \%$ of the professional work force in the United States, they comprise only about $13 \%$ of the science and engineering work force (NSF, 1984). The growing number of women entering different professions is evidence of great strides toward equality (Bureau of the Census, 1984); however some have suggested that continued inequities in mathematics and science preparation may relegate women to lower-paying, traditionally female positions at all levels of the occupational hierarchy (e.g., Eccles, 1984; Eccles and Hoffman, 1984; Klein, 1985; Stage et al., 1985).

Despite the accumulation of a large body of research on the topic of effective sex equity practices in the schools, little progress has been made in changing educational procedures, suggesting the need to reexamine the role of research in the policy and program-planning picture. Most researchers in this area hope that their research findings eventually will make their way into practice, but are disillusioned by the rate of change. Several good reasons for this situation exist. One is that most researchers do not have a detailed knowledge of the policy process. A second reason is that the application of research to educational policies often is limited to federal or state legislation, rather than aimed at district or classroom equity programs that rely on research. Finally, researchers seldom are aware of the implementation of their findings. Equity research has been used in program planning, teacher training, and some policy decisions, but those generating the research often do not know it. With the overarching goal of linking mathematics and science equity research and implementation, this review has three objectives: (1) to review the current state of research knowledge; (2) to examine the ways research has been applied to existing mathematics and science equity programs; and (3) to suggest ways in which the connections between research and policies can be strengthened.

\section{REVIEW OF THE RESEARCH}

We have chosen to group the research into the following categories: (a) person-centered research, focusing on characteristics and interactions of 
students and teachers; (b) instructional context research, focusing on how tests, instructional materials, and the structure of the classroom environment influence student achievement; and (c) macrolevel demographic research, emphasizing enrollment patterns in mathematics and science classes, and choices of different occupations. Although a comprehensive review is not feasible here, the interested reader is referred to several excellent sources for more detailed reviews of different aspects of this work (see Chipman et al., 1985; Eccles, 1985; Fennema and Sherman, 1977; Scott and Schau, 1985; Stage et al., 1985).

\section{Person-Centered Research}

Much of the person-centered research has focused on biological and performance differences between the sexes. Recent studies suggest that gender accounts for only 1-5\% of the variance in any observed differences (see Linn and Peterson, 1985). Linn and Peterson argue that such differences should not limit career options for either boys or girls, and certainly cannot explain the larger differences in mathematics and science career participation between men and women. In terms of gender differences in mathematics performance, Stage et al. (1985) reviewed evidence showing that boys perform slightly better on mathematics reasoning problems (word/story problems) than girls do in high school. Boys and girls perform equally well on algebraic and basic skills kinds of problems, whereas girls sometimes perform better than boys on computational skill problems. In their review of the literature, they found no systematic differences in mathematics achievement until the tenth grade, and after that the differences were small, favoring boys. In a recent study with younger children, Marshall and Smith (1987) found girls outperforming boys in all areas of mathematics in the third grade, but by sixth grade much of this advantage had disappeared. They suggested an explanation based on differences, focusing on the finding that females develop automaticity (the ability to process information quickly while using little processing attention) earlier than males.

In science, performance differences between boys and girls largely have been attributed to differential course-taking. In both the United States and England, girls typically are overrepresented in biology, underrepresented in physics, and the gap between the sexes in chemistry seems to be closing (Benbow and Minor, 1986; Kelly, 1987). However, girls do not take as many science courses as boys. In one large study $74 \%$ of boys completed the entire science sequence offered in high school, while only $56 \%$ of the girls did so (Benbow and Minor, 1986). The authors of these studies suggested that sex differences in science performance may be related to differences in mathematical skills. 
Although girls and boys perform similarly, teachers may hold stereotypes about the relative abilities of the sexes. Spear (1984) found that teachers award higher marks to identical science papers if they think they are written by boys rather than girls. When teachers were asked to evaluate identical science papers, varying only the supposed sex of the author, work attributed to boys was rated significantly higher on richness of ideas, greater interest in the topic, scientific accuracy, organization of ideas, and conciseness. Girls received consistently higher marks only for neatness. Teachers also believed that science education is more important for boys than girls (Spear, 1987).

Research on teacher-student interaction has burgeoned in recent years (see Good and Brophy, 1978). Most of the research related to sex equity has focused on how boys and girls are treated differently in mathematics and science classes. In some mathematics and science classrooms, boys received more instructional time and encouragement from teachers; received more precise feedback about their work; and high-ability boys got more praise and interacted more with mathematics teachers than did high-ability girls (Becker, 1981; Sadker and Sadker, 1986; Leinhardt et al., 1979; Parsons et al., 1982). Fennema (1986) suggested that these classroom practices may lead boys to learn to be more independent and to develop more complex cognitive strategies for dealing with mathematics. Similar findings have been reported for science classrooms. Teachers interacted more with boys than girls in both biology and physics classes (Crossman, 1987). Although this was found for both female and male teachers, the effect was largest for female teachers. It should be noted that such differences were not found in all classrooms, and so all teachers did not treat boys and girls differently. However, even when teachers did not treat boys and girls differently, they often used gender as a way to assign tasks, choose teams, or illustrate a point. Buswell (1981) found that girls and boys in elementary school were classified by gender approximately 20 times per day. Stanic and Reyes (1986) suggested that differential student outcomes can result even from equal teacher treatment (see also Bossert, 1982); that is, boys and girls may interpret the treatment they receive in different ways, even if that treatment is "objectively" the same.

In addition to direct interaction with students, teachers may influence students by providing appropriate role models. Studies have shown that female participation in mathematics and science can be increased through exposure to female role models (Brody and Fox, 1980; Tobin and Fox, 1980), such as female mathematics and science teachers, films and books about careers requiring mathematics, contributions of females to science or mathematics, or visitors from nontraditional occupations. Related to the rolemodel approach are programs based on the research suggesting the importance of supportive mentors for females (Speizer, 1981; Tidball and Kistiakowsky, 1976). The major difference between the two approaches is 
that mentors usually become more involved with certain individuals, rather than serving as role models for the whole group. Little data is available on the success of the mentoring approach because the target females have not been followed over time.

The differential treatment received by girls and boys in the early grades may lead to different mathematics and science self-efficacy beliefs, ultimately influencing academic and career choices. Research indicates that mathematics self-efficacy beliefs are significantly related to the selection of sciencebased college majors (Betz and Hackett, 1983), and that self-efficacy acts as a mediator between gender, performance, and mathematics choices in college (Hackett, 1985). Additional evidence for the importance of high school attitudes comes from a study by Ethington and Wolfle (1988), indicating that one of the strongest effects on college major was intended field of study and number of mathematics courses taken during high school.

\section{Instructional Context Research}

Research on instructional materials used in classrooms provides some important clues concerning why girls may be less likely to keep taking mathematics courses. Researchers have found that exposure to sex-biased materials increases sex-typed attitudes, particularly when students are still developing their ideas about sex roles, as in the early elementary grades (Scott and Schau, 1985). Since mathematics and especially science are often viewed as male subjects, exposure to sex-biased materials could lessen girls' interest in mathematics and science. The construction of these subjects as masculine is not surprising given what students encounter in their learning environments. Kelly (1987) reported that more males work in science, take science classes, teach science classes, and are pictured in science textbooks all over the world.

Other studies have shown how bias in educational testing in general can influence students' achievement (see Rosser, 1987). Much of the research has focused on race and ethnic bias, but some studies have examined the effects of particular kinds of test items on females' test performance (Donlon et al., 1979; McCarthy, 1975; see Diamond and Tittle, 1985, for a review). This work shows that sex bias in testing manifests itself primarily in test items that reflect the experiences of traditional male roles, and females perform less well on those kinds of items. If girls perform more poorly on standardized mathematics tests, they may be more likely to stop taking mathematics when that option becomes available to them. Therefore, the choice of a standardized test is a critical one.

A second area of research concerning instructional context is the way in which information in mathematics and science classes is presented. Find- 
ings from a demonstration project conducted in England by Kelly (1987; Kelly et al., 1985) suggested that teachers could increase the likelihood that females will stay interested in certain mathematics or science areas by choosing topics of equal interest to females and males. Evaluations of this project showed that students held less stereotyped views about females' participation in science and held more positive attitudes toward science and scientists in general after participation.

Another area of research in this category is the work on classroom environment, usually defined as the motivational strategies and classroom organization teachers use. In one study, teachers used competition between boys and girls as a means of motivating and controlling the boys, and segregated boys and girls for many activities (Delamont, 1980). Both of these classroommanagement strategies reinforce traditional stereotypes and inhibit females' motivation to study mathematics (Ames, 1984). This suggestion is supported by the findings from a recent study in which different types of mathematics classrooms were compared (Eccles et al., 1986). Girls had more positive attitudes toward mathematics in classrooms where there were fewer competitive activities, less social comparison, more cooperation, and greater teacher fairness. Peterson and Fennema (1985) also reported that cooperation in mathematics activities facilitated girls' mathematics performance. Casserly's (1975) research indicated that girls may need to receive active encouragement from teachers if they are to continue in mathematics. Lockheed and Harris (1978) suggested that teachers need to build equal status interactions into the structure of activities by using cooperative, mixed-sex groups. Intervention studies using these techniques have shown that they reduce sex stereotypes of the participants (Lockheed and Harris, 1978, 1982). Another organizational strategy found in most elementary school classrooms is sex segregation in seating assignments. Sadker and Sadker (1986) found that teachers tend to gravitate to the boys' sections in these segregated classrooms and spend most of their time there, accounting for the greater number of interactions boys have with teachers.

Finally, research on the educational environment at the school rather than classroom level suggests that choices about major school transition points (e.g., middle schools vs. junior highs) may affect males and females differently. Research on gender-role development suggests that early adolescence may be a period of increased awareness of one's own gender role and a need to feel secure in that role (Hill and Lynch, 1983). Females enter puberty before males and may feel the need to conform to appropriate gender roles quite strongly at this time, due to the expectations of peers and other socializers. These changes may occur at the same time females are being asked to make choices between continuing in mathematics (a stereotypically male area) or a more female-typed area, such as English or the arts. Studies have 
shown that girls became increasingly negative about mathematics as they moved into junior high (Eccles, 1984); that self-esteem and achievement motivation were lowest for pubertal girls interested in dating (Simmons et al., 1973); and that girls who continued in science at the highest levels often considered themselves unattractive and unfeminine (Smithers and Collings, 1981). Similarly, Roberts (1986) found that popularity, gender, and course grades interacted during the junior high years, with females who cared about popularity having the lowest course grades. In addition, parents' ratings of the difficulty of mathematics for their daughters during the transition to junior high has been related to pubertal status (Eccles et al., 1987). Separating females and males for science classes during these critical periods has been shown to improve girls' attitudes and achievement (Smith, 1984). These results suggest that course choices may be introduced at the wrong time for females, leading them to choose stereotypically female courses, thus limiting their later career possibilities.

\section{Demographic Research}

Despite the highly publicized differences between the SAT-mathematics scores of males and females (see Benbow and Minor, 1986; Benbow and Stanley, 1980), girls typically receive higher grades in mathematics than boys throughout high school (Eccles et al., 1984). But, do they take the same classes? Research focusing on differential course participation of males and females in mathematics and science shows mixed results. Some national enrollment data show equivalent enrollments in high school mathematics courses for females and males except at the highest level of calculus (Armstrong, 1980). Similarly, an analysis of 13,000 high school transcripts conducted by West et al. (1985), revealed that males and females were about equally likely to have earned four or more credits in mathematics, with at least one earned in an advanced mathematics course. Others have found differences in enrollment patterns. Chipman et al. (1985) reported that current enrollment across the U.S. in advanced high school mathematics courses is about $60 \%$ male and $40 \%$ female. West and Gross (1986) found that males were more likely than females to have taken higher level mathematics by their junior year in high school. Thirty-three percent of males and $28 \%$ of females graduating in 1982 took at least three years of science; $48 \%$ of males and $45 \%$ of females took at least two years of science; however, females clearly concentrated in the life sciences, while males took both life and phyical sciences (U.S. Department of Education, 1984).

Although few states keep detailed course enrollment figures, and these are seldom broken down by class type, some investigations from different 
states show sex differences in course-taking even at intermediate levels. In California, females were less likely to take Algebra II than males (California Basic Educational Data System, 1981); and in Michigan, by eleventh grade only $51 \%$ of females were enrolled in mathematics, compared to $61 \%$ of males (Gise, 1980).

\section{PROGRAMS LINKING RESEARCH AND POLICY}

In conceptualizing the links between policy and research, it is essential to distinguish among the different levels at which policy is carried out. Educational policies regarding sex equity are created and carried out at many levels, including federal, regional, state, district, and classroom. Thus, depending on which level is addressed, policy-makers may be legislators, state office of education personnel, school board members, district superintendants, principals, or classroom teachers.

Many excellent programs to promote sex equity in mathematics and science education have been developed, and the programs often utilize research findings to develop the strategies they employ (see Stage et al., 1985 for a complete review of exemplary programs). These programs include: (1) regional programs that administer sex-equity programs to districts across several states; (2) state-level programs housed in state departments of education that work with individual districts within the state; and (3) school district and individual school programs to promote sex equity.

\section{Regional Level}

The coordination of technical services and the enforcement of Title IX and Title IV have occurred at the regional level, and Sex Desegregation Centers have been established around the country to provide these services. An example of a regional program is the Planned Change Model, used at the Michigan Center for Sex Equity in the Schools (Linn, 1984). This model utilizes findings from both person-centered and instructional-context research to identify problems within the district, develop an action plan, and implement the plan. Such programs are typically introduced in districts that ask for them, based on the assumption that the effects of sex-equity programs are more likely to be long-lasting if the district desires change than if it is forced to participate in a program.

\section{State Level}

There have been a variety of good equity intervention models developed at the state level. For example, the California Coalition for Sex Equity in 
Education (CCSEE), funded by the Women's Educational Equity Act in 1978 (McDonald, 1981), is a coalition of the Sex Desegregation Assistance Center for Region IX, the California State Department of Education, the California School Boards Association, and the Association of California Administrators. Again, those involved in this program developed equity programs based on the findings from the research reviewed earlier. In addition, they used research from social psychology and business management to plan their implementation strategy, which consisted of identifying key decision-makers and sex-equity advocates in 36 school districts. These key individuals helped gain access to classrooms and helped to effect change in their districts. Such equity intervention programs have had positive effects, although their success depends on the kinds of school districts involved, as well as the types of activities chosen (see Schmuck et al., 1985 for a more detailed discussion). A similar model of state-level intervention is used by the Michigan Office of Sex Equity. A major component of this office's On Site Long Range Planning Model (OSP) is the involvement of people at the district level in planning and implementing change strategies so that gains will continue even after the state-level support is withdrawn.

\section{District and Individual School Levels}

Research findings seem to have had their greatest impact on interventions at the district and individual school levels. School districts can do a variety of things to promote equity. For example, promoting females to higher administrative positions; structuring the system so that course decisions and/or school transitions are made at the most advantageous time for both males and females; choosing sex-fair textbooks and other curriculum materials; incorporating nonstereotyped information into career counseling and the vocational curriculum; and providing in-service training on sex equity in the classroom. Although these actions may not represent an equity "program," most of them have been prompted by the research findings reviewed earlier.

An example of in-service training is provided by Project EQUALS, based in California. This project offers staff development programs for teachers, counselors, and administrators that include increasing awareness of research findings in the area of differential treatment in the classroom; providing materials to be used in the classroom; and modeling a variety of instructional techniques to improve students' attitudes toward mathematics (Kreinberg, 1981). Sadker and Sadker (1986) have provided similar training for K-12 teachers and for college professors. When the teachers participating in their training were compared to a matched sample who had not received the training, Sadker and Sadker found that the trained instructors had significantly higer rates of interaction, more precise reactions, more academic contacts, and a greater number of student-initiated comments from both fe- 
males and males than the untrained instructors. A similar project to train principals, the Principal Effectiveness-Pupil Achievement Project (PEPA), gave principals the skills they need to lead the improvement of instructional equity and effectiveness in their schools (Sadker and Sadker, 1986).

Many of the programs in individual schools have been implemented at a classroom level. Generally, change at this level is not thought of as a policy change unless it is mandated at higher levels. However, this is the level at which much of the person-centered and instructional-context research on gender differences in mathematics and science has been focused, and where the links between educational practice and research are most clear. Many examples of programs aimed at this level can be found. Based on the findings concerning the value of role models, many successful equity-intervention programs have included a role-modeling component. A good example of this kind of program is the Career-Oriented Modules for Exploring Topics in Science (COMETS) at the University of Kansas (Smith et al., 1982). This program offered modules for grades five through nine, using three different types of role models: (1) a community resource person who spent time in the classroom talking about her career; (2) famous women scientists in history; and (3) contemporary women in science and engineering.

Related to the role-model approach are programs based on the research suggesting the importance of supportive mentors for females (Speizer, 1981; Tidball and Kistiakowsky, 1976). Intervention programs have begun to use a mentor model or nurture groups to provide active support. An example is the Academy in Mentoring at Easter Michigan University (Van Voorhees, 1985). This program provided training in mentoring skills for junior high teachers and counselors who served as mentors for academically able girls. The activities were designed to provide teachers and counselors with information about how to provide support and encouragement to adolescent girls so that they will elect and be successful in courses in mathematics, science, and technology.

Research reviewed earlier on the importance of presenting mathematics and science information so that it appeals to both boys and girls has led to programs such as an intervention project in England called Girls Into Science and Technology (GIST) (Kelly et al., 1984). In planning this program, the researchers tried to make science more accessible to girls by emphasizing nurturing topics more than analytical-instrumental topics. This included a shift away from the development of rules to one emphasizing concern for people and outcomes. Teachers were taught to link physics principles to human biology wherever possible. For example, the study of light was introduced by studying the human eye, and an investigation of record and tape players led to the study of circuitry (Smail, 1984). Evaluations of this project showed that students held less stereotyped views about females' 
participation in science and held more positive attitudes toward science and scientists in general after participation.

\section{IMPROVING RESEARCH-POLICY LINKS}

\section{Recommendations for Policy}

Despite the many ways in which recent findings from sex-equity research have been utilized to inform program and policy planners, many researchers feel that their findings are only used at a minimal level. This section addresses some reasons for the research-implementation gap, keeping the limitations imposed by the current financial and political climate in mind. It concludes by giving some recommendations for ways to increase the use of research results at each of the policy levels reviewed earlier.

\section{Regional Level}

For a number of reasons, many sex-equity programs are limited in what they can accomplish. Lack of funding is one primary reason. Second, there often is not a great deal of coordination of the programs, so that efforts sometimes are duplicated. For instance, the state-level and regional-level programs often resemble each other and serve similar geographic areas, yet the programs have separate (and often competing) administrative structures. Third, there have been few systematic evaluations of different equity programs, therefore information on program effectiveness is not available. Perhaps the major reason is that the majority of programs are limited to serving only school districts that have expressed an interest in having a sexequity program. Hence, many districts receive no programs, and these districts may be the ones that need programs the most. The reason for this situation is that the enforcement provisions of Title IX are not strictly followed, resulting in few negative consequences for noncompliance. Sex equity has not received the attention it deserves in the debate on how to attain educational excellence, and so it has not been a high priority in many areas.

\section{State Level}

Again, there are a limited number of activities carried out at this level. It is impossible for states to monitor "equal" treatment in individual classrooms. However, states often have great control over course requiremens, testing programs, and teacher licensure. These are places to focus relevant 
research findings. Based on the course-enrollement findings, one strategy that could be used (and one that some states are adopting) would be to increase the course requirements for mathematics, science, and computers at the high school level so that females do not elect themselves out of these courses too early. This practice would also lessen the burden on parents to push their children into certain courses, and females to choose courses they may think are "not for girls." If states became more systematic about obtaining courseenrollment data, they could better chart their own progress in attaining equity, and target interventions toward the areas that have the most unequal enrollment patterns.

State offices of education often control the kinds of achievement tests used to assess student progress. Most states now have their own state-wide testing programs, which are often linked to graduation. Officials designing or selecting tests to be used in different state-wide testing programs should be made aware of the problem of sex bias in test construction, so that they can choose tests that are more fair.

State laws also determine the licensing of teachers. As we just discussed, researchers examining teacher-student interaction find that boys and girls often receive differential treatment from mathematics and science teachers, and teachers often are unaware of this bias in their behavior. These findings suggest that states should require a course in sex and race equity as part of teacher preparation. Alternatively, guidelines could be developed for the incorporation of this information into other teacher-training courses.

\section{District and Individual School Levels}

Administrators at these levels make many important decisions that can influence girls' continued participation in mathematics and science courses. These include deciding when various school transitions are made, what kinds of materials are used in classrooms, and the kinds of counseling that are done with students. Concerning school transitions (e.g., whether to middle schools or junior highs), the research reviewed earlier on gender-role development suggests that early adolescence may be the worst time to introduce course choices and a new school, particularly for girls. School districts might use this information to decide when to introduce these transitions.

School districts usually have control over the kinds of textbooks, other curriculum materials, and tests to be used in the classroom, provide in-service training for teachers, and make resource people available to teachers. In each of these areas strategies to promote equity could be included in the decisions that are made and programs that are offered. Instructional materials used in classrooms have changed to some extent, but more change is needed. Districts should also check textbooks, library books, and tests for bias, and should actively seek materials showing sex-fair portrayals of women in careers 
requiring mathematics and science. Measures should also be taken to ensure that both girls and boys are pictured in book illustrations, bulletin board materials, and educational movies. Equity in mathematics and science can be included as goals when making district-wide curriculum decisions, with specific behavioral objectives set for each grade level.

Programs promoting the feasibility of entering nontraditional occupations could be incorporated into the counseling or vocational curriculum. Students' attitudes may be less stereotyped after they receive such information. However, they still may need more information about the kind of training different careers require. Adolescents often hold unrealistic goals about the kinds of careers they will have, and what educational requirements are needed to begin certain careers. Fottler and Bain (1984) found that $56 \%$ of high school seniors aspire to be in professional and technical occupations, although only $15 \%$ of the U.S. labor force is actually in such occupations. The importance of advanced mathematics and science courses for the pursuit of many careers could be incorporated into career counseling and, perhaps more importantly, accurate career information could be added to mathematics/science classes. The research reviewed earlier concerning females' low mathematics self-efficacy also suggests the need for counselors to address females' self-perceptions of their abilities in addition to past performance and test scores.

The availability of a Title-IX coordinator as a resource person may also be made known so that teachers may go to that person with questions and complaints about bias. This strategy is not used in very many districts. Although a Title-IX coordinator must be designated in each district by law, the information is often not highly publicized, and the designated person often has many other duties (Giese, 1980). Most districts would benefit if they provided a job description, resources, and goals for the Title-IX coordinator, and then provided information to all teachers in the district about who the coordinator is and what their responsibilities are.

The large body of research focused on teacher-student interaction patterns and classroom characteristics that foster female participation in mathematics and science courses could be incorporated into district in-service programs for teachers, and could also be made available to principals and teachers to help structure their classrooms in "girl friendly" ways. If a school or district made sex equity a priority, teachers could be taught ways to monitor their progress in obtaining more equitable interaction patterns and classroom structures.

\section{Recommendations for Research}

In this review, equity research was deliberately categorized, based on its target group, and the policy levels at which most research will be used 
were further typed. A major task for researchers is selecting an appropriate policy level at which to do their research. This is true during both the initial steps of framing the research question and again when deciding how to convey important findings.

Most of the equity research that has been conducted falls into the person-centered and instructional-context categories, giving us a good knowledge-base about the important developmental, interactional, and instructional variables in these areas. Many of the successful intervention programs have utilized this information. Future research in these areas will need to become more refined in order to deal with the increasingly subtle differences in the ways in which boys and girls are treated in mathematics and science classes.

Far fewer studies focusing on demographic trends and evaluation of existing programs have been conducted, and these areas need to receive more emphasis in future research efforts. More fine-grained demographic information about course-enrollment patterns would increase our understanding of where progress has been made, and where more effort should be placed. Similarly, more systematic evaluations and comparisons of existing programs are needed to determine which ones work best, and to aid in the implementation of successful programs in diverse settings.

Beyond performing more studies, researchers need to think more carefully about two other issues. First, there is a need to communicate research findings to policy-makers in more effective ways. There are many ways this could be done. These include: (a) preparing clear, concise summaries of research results for dissemination to equity experts, program planners, and school district personnel; (b) disseminating feedback to schools and teachers involved in equity-related research projects, and giving in-service presentations for local school districts; (c) writing summaries of findings for school newsletters or giving presentations for parent-teacher organizations; (d) getting involved in planning state-testing goals, course enrollment requirements, and textbook selection; (e) consulting with textbook companies; and (f) summarizing results to be used as press releases for the media by colleges or universities.

Additionally, researchers could make better use of existing forums to reach policy-makers. Several such forums are available. One place to find sex-affirmative materials and ideas for classrooms is the Women's Educational Equity Act Publishing Center at the Education Development Center in Newton, Massachusetts. A second source is a list of existing precollege mathematics and science programs for minority and/or female students recently published by the Office of Opportunities within the American Association for the Advancement of Science (AAAS). A third forum is the American Educational Research Association's Editor-at-Large Program, involv- 
ing a network of researchers and writers who prepare significant research findings for the popular press and nonresearch education publications. Beyond these outlets, there is a need for a clearinghouse for equity-relevant research reports, where abstracts could be collected and disseminated to equity experts, program planners, and other policy-makers. There also is a need to circulate a list of people and offices who would like to receive summaries of current research from researchers in the field of sex equity.

Finally, researchers and policy-makers at all levels need to work together more closely, so that intervention programs to achieve equity can be designed and implemented more efficiently. Increased discussion between researchers and policy-makers could lead researchers to assess issues that are more central to the concerns of policy-makers, as well as to provide expertise in evaluating ongoing intervention projects. Such discussion also would give policy-makers more direct access to research findings when they need them, as well as more input into the design of future research efforts. Researchers, program planners, and other policy-makers would all benefit by having more opportunities to learn from each other and work together toward the common goal of attaining more equitable educational practices.

\section{ACKNOWLEDGMENTS}

We would like to express our appreciation to Paul Pintrich for his helpful comments on an earlier version of this manusript. Writing of this paper was supported in part by grant BNS-8510504 fron the National Science Foundation to Jacquelynne Eccles and Allan Wigfield.

\section{REFERENCES}

Ames, C. (1988). Competitive, cooperative, and individualistic goal structures: A cognitivemotivational analysis. In Ames, R., and Ames, C. (eds.), Research on Motivation in Education, Vol. I, Academic Press, Orlando, Florida, pp. 177-277.

Armstrong, J. (1980). Achievement and participation of women in mathematics. Final report to the National Institute of Education, Washington, D.C.

Becker, J. R. (1981). Differential treatment of females and males in mathematics classes. $J$. Res. Math. Educat. 12: 40-54.

Benbow, C. P., and Minor, L. L. (1986). Mathematically talented males and females and achievement in the high school sciences. Am. Educat. Res. J. 23: 425-436.

Benbow, C. P., and Stanley, J. C. (1980). Sex differences in mathematical ability: Fact or artifact? Science 210: 1262-1264.

Betz, N. E., and Hackett, G. (1983). The relationship of mathematics self-efficacy expectations to the selection of science-based college majors. J. Voc. Behav. 23: 329-245.

Brody, L., and Fox, L. H. (1980). An accelerated intervention for mathematically gifted girls. In Fox, L. H., Brody, L., and Tobin, D. (eds.), Women and the Mathematical Mystique, Johns Hopkins University Press, Baltimore, Maryland. 
Bureau of the Census (1984). Detailed Occupation of the Experienced Civilian Labor Force by Sex for the United States and Regions: 1980-1970, U. S. Dept. of Commerce, Washington, D.C.

Buswell, C. (1981). Sexism in school routines and classroom practices. Durham and Newcastle Res. Rev.9: 195-200.

California Basic Educational Data System (1981). Student Enrollment by Subject in California Public Schools for 1980-1981, California State Department of Education, Sacramento.

Casserley, P. (1975). An assessment of factors affecting female participation in advanced placement programs in mathematics, chemistry, and physics. Report to the National Science Foundation, Washington, D.C.

Chipman, S. F., Brush, L. R., and Wilson, D. M. (1985). Women and Mathematics: Balancing the Equation, Erlbaum, Hillsdale, New Jersey.

Clark, D. L., and Astuto, T. A. (1986). The significance and permanence of changes in federal education policy. Educat. Res. 15: 4-13.

Crossman, M. (1987). Teachers' interactions with girls and boys in science lessons. In Kelly, A. (ed.), Science for Girls? Open University Press, Milton Keynes, England, pp. 58-65.

Delamont, S. (1980). Sex Roles and the School, Methuen, London.

Diamond, E. E., and Tittle, C. K. (1985). Sex equity in testing. In Klein, S. S. (ed.), Handbook for Achieving Sex Equity Through Education, Johns Hopkins University Press, Baltimore, Maryland, pp. 167-188.

Donlon, T. F., Ekstrom, R. B., and Lockheed, M. E. (1979). The consequences of sex bias in the content of major achievement test batteries. Meas. Eval. Guid. 11: 202-216.

Eccles, J. S. (1984). Sex differences in mathematics participation. In Steinkamp, M. and Maehr, M. L. (eds.), Advances in Motivation and Achievement, Vol. 2, University of Chicago. Press, Chicago, Illinois, pp. 367-420.

Eccles, J. S., Adler, T. F., and Meece, J. L. (1984). Sex differences in achievement: A test of alternate theories. J. Personal. Soc. Psychol. 46: 26-43.

Eccles, J. S., Mac Iver, D., and Lange, L. (1986). Classroom practices and motivation to study math. Paper presented at the annual meeting of the American Educational Research Association, San Francisco, California.

Eccles, J. S., Flanagan, C., Goldsmith, R., Jacobs, J., Jaryaratne, T., Wigfield, A., and Yee, D. (1987). Parents as socializers of achievement attitudes. Paper presented at the biennial meeting of the Society for Research in Child Development, Baltimore, Maryland.

Eccles, J. S., and Hoffman, L. W. (1984). Socialization and the maintainence of sex-segregated labor market. In Stevenson, H. W., and Siegel, A. E. (eds.), Research in Child Development and Social Policy, Vol. 1, University of Chicago Press, Chicago, Illinois.

Ethington, C. A., and Wolfle, L. M. (1986). Women's selection of quantitative undergraduate fields of study: Direct and indirect influences. Am. Educat. Res. J. 25: 157-176.

Fennema, E., and Sherman, J. (1977). Sex-related differences in mathematics achievement, spatial visualization, and affective factors. Am. Educat. Res. J. 14: 51-71.

Fennema, E. (1986). Autonomous learning behaviors and classroom environments. Paper presented at the annual meeting of the American Educational Research Association, San Francisco, California.

Fottler, M. D., and Bain, T. (1984). Realism of occupational choice among high school seniors: Implications for quality of work life. J. Occupat. Behav. 5: 237-251.

Giese, E. (1980). You can see the cat walking. . . A report on the findings of the Michigan Project on Equal Education Rights, Michigan PEER, Milford, Michigan.

Good, T. L., and Brophy, J. E. (1978). Looking in Classrooms, Harper \& Row, New York.

Hackett, G. (1985). Role of mathematics self-efficacy in the choice of math-related majors of college women and men: A path analysis. J. Counsel. Psychol. 32: 47-56.

Hall, E. R., and Post-Kammer, P. (1987). Black mathematics and science majors: Why so few? Vocat. Guid. Q. 35: 206-219.

Harvey, G., and Klein, S. S. (1985). Understanding and measuring equity in education: A conceptual model. J. Educat. Eq. Lead. 5: 145-168.

Hill, J. P., and Lynch, M. E. (1983). The intensification of gender-related role expectations during early adolescence. In Brooks-Gunn, J., and Peterson, A. (eds). Girls at Puberty, Plenum, New York, pp. 201-228. 
Kelly, A. (1987). Why girls don't do science. In Kelly, A. (ed.), Science for Girls? Open University Press, Milton Keynes, England, pp. 12-17.

Kelly, A., Whyte, J., and Smail, B. (1985). Girls into science and technology: Final report. Department of Sociology, University of Manchester, Manchester, England.

Klein, S. S. (ed.) (1985). Handbook for Achieving Sex Equity Through Education, Johns Hopkins University Press, Baltimore, Maryland.

Klein, S. S., and Simonson, J. (1984). Increasing sex equity in education: Roles for psychologists. Am. Psychol. 39: 1187-1192.

Klein, S. S., Russo, L. N., Tittle, C. K., Schmuck, P. A., Campbell, P. B., Blackwell, P. J., Murray, S. R., Dwyer, C. A. Lockheed, M. E., Landers, B. and Simonson, J. R. (1985). Summary and recommendations for the continued achievement of sex equity in and through education. In Klein, S. S. (ed.), Handbook for Achieving Sex Equity Through Education, Johns Hopkins University Press, Baltimore, Maryland, pp. 439-519.

Kreinberg, N. (1981). 1,000 teachers later: Women, mathematics, and the components of change. Pub. Affairs. Rep. 22: 1-7.

Leinhardt, G., Seewald, A. M., and Engle, M. (1979). Learning what's taught: Sex difference in instruction. J. Educat. Psychol. 71: 432-439.

Linn, M. C., and Peterson, A. C. (1985). Facts and assumptions about the nature of sex differences. In Klein, S. S. (ed.), Handbook for Achieving Sex Equity, Johns Hopkins University Press, Baltimore, Maryland, pp. 53-77.

Linn, E. (1984). Math Equity: Planned Change Model, Center for Sex Equity in the Schools, School of Education, University of Michigan, Ann Arbor, Michigan.

Lockheed, M. E., and Harris, A. M. (1978). The effects of equal cross-sex contact on students' sex stereotyped attitudes and behavior. Paper presented at the annual meeting of the American Education Research Association, Toronto.

Lockheed, M. E., and Harris, A. M. (1982). Classroom interaction and opportunities for cross-sex peer learning in science. J. Early Adol. 2: 135-143.

Marrett, C. (1986). On minority females in precollege math. Paper presented at the annual meeting of the American Educational Research Association, San Francisco, California.

Marshall, S. P., and Ssmith, S. D. (1987). Sex differences in learning mathematics: A longitudinal study with item and error analyses. J. Educat. Psychol. 79: 372-383.

McCarthy, K. (1975). Sex bias in tests of mathematical aptitude. Unpublished doctoral dissertation, City University of New York, New York.

McDonald, S. C. (1981). An inquiry into the resilience of Title IX reforms at the local level. Paper presented at the annual meeting of the American Educational Research Association, Los Angeles, California.

National Research Council (1980). Science and Engineering Doctorates in the United States, National Academy of Sciences, Washington, D.C.

National Science Foundation (1984). Women and Minorities in Science and Engineering, National Science Foundation, Washington, D.C.

National Science Foundation (1985). Women and Minorities in Science and Engineering, National Science Foundation, Washington, D.C.

Parsons, J. E., Kaczala, C., and Meece, J. (1982). Socialization of achievement attitudes and beliefs: Classroom influences. Child Devel. 53: 322-339.

Peterson, P. L., and Fennema, E. (1985). Effective teaching, student engagement in classroom activities, and sex-related differences in learning mathematics. Am. Educat. Res. J. 22: 309-335.

Roberts, L. R. (1986). Gender differences in patterns of achievement and adjustment during early adolescence. Paper presented at the biennial meeting of the Society for Research in Adolescence, Madison, Wisconsin.

Rosser, P. (1987). Sex Bias in College Admissions Tests: Why Women Lose Out, National Center for Fair and Open Testing, Cambridge, Massachusetts.

Rosser, P. (1988). Girls, boys, and the SAT: Can we even the score? NEA Today 48-53.

Sadker, M., and Sadker, D. (1986). Sexism in the classroom: From grade school to graduate school. Phi Delta Kappa, 67: 512-515. 
Schmuck, P. A., Adkison, J. A., Peterson, B., Bailey, S., Glick, G. S., Klein, S. S., McDonald, S., Schubert, J., and Tarason, S. L. (1985). Administrative strategies for institutionalizing sex equity in education and the role of government. In Klein, S. S. (edd.), Handbook for Achieving Sex Equity Through Education, Johns Hopkins University Press, Baltimore, Maryland, pp. 95-123.

Scott, K. P., and Schau, C. G. (1985). Sex equity and sex bias in instructional materials. In Klein, S. S. (ed.), Handbook for Achieving Sex Equity Through Education, Johns Hopkins University Press, Baltimore, Maryland, pp. 218-232.

Simmons, R. G., Rosenberg, F., and Rosenberg, G. (1973). Disturbance in the self-image at adolescence. Am. Sociol. Rev. 38: 553-568.

Smail, B. (1984). Girl-friendly science. Reprinted in Kelly, A. (ed.), Science for Girls? Open University Press, Milton Keynes, England, pp. 80-88.

Smith, S. (1984). Single sex setting. In Deem, R. (ed.), Co-education Reconsidered, Open University Press, Milton Keynes, England.

Smith, W. S., Molitor, L. L., Nelson, B. J., and Matthew, C. E. (1982). Career Oriented Modules to Explore Topics in Science, University of Kansas, School of Education, Department of Curriculum and Instruction, Lawrence, Kansas.

Smithers, A., and Collings, J. (1981). Factors differentially affecting the science subject preferences, choices and attitudes of girls and boys. In Kelly, A. (ed.), The Missing Half: Girls and Science Education, Manchester University Press, Manchester, England.

Spear, M. G. (1984). The biasing influence of pupil sex in a science marking exercise. Res. Sci. Technol. Educat. 2: 55-60.

Speizer, J. J. (1981). Role models, mentors, and sponsors: The elusive concepts. Signs 6: 692-712.

Stage, E. K., Krienberg, N. L., Eccles, J. S., and Becker, J. R. (1985). Increasing the participation and achievement of girls and women in mathematics, science, and engineering. In Klein, S. S. (ed.), Handbook for Achieving Sex Equity Through Education, Johns Hopkins University Press, Baltimore, Maryland, pp. 237-268.

Stanic, G. M. A., and Reyes, L. H. (1986). Gender and race differences in mathematics: A case study of a seventh-grade classroom. Paper presented at the annual meeting of the American Educational Research Association, San Francisco, California.

Tidball, M. E., and Kistiakowsky, V. (1976). Baccalaureate origins of American scientists and scholars. Science. 193: 646-652.

Tobin, D., and Fox, L. H. (1980). Career interests and career education: A key to change. In Fox, L. H., Brody, L., and Tobin, D. (eds.), Women and the Mathematical Mystique, Johns Hopkins University Press, Baltimore, Maryland.

U.S. Department of Education (1984). Science and Mathematics Education in American High Schools: Results from the High School and Beyond Study, National Center for Education Statistics, Washington, D.C., NCES 34-211b.

U.S. Department of Education, National Commission on Excellence in Education (1983). $A$ nation at Risk: The Imperative for Educational Reform, U.S. Government Printing Office, Washington, D.C.

Van Voorhees, B. (1985). The Academy in Mentoring, Eastern Michigan University, College of Education, Ypsilanti, Michigan.

West, J., and Gross, S. (1986). Performance of women and minorities in mathematics: A large school system perspective. Paper presented at the annual meeting of the American Educational Research Association, San Francisco, California.

West, J., Miller, W., and Diodata, L. (1985). An Analysis of Course-Taking Patterns as Related to Student Characteristics, National Center for Education Statistics, Washington, D.C. 